\title{
Nursing Professionals' Conception on Palliative Care
}

\author{
Yullia Abreu Viana1, Leila de Cássia Tavares da Fonsêca², \\ Solange Fátima Geraldo da Costa ${ }^{3}$, \\ Francileide de Araújo Rodrigues ${ }^{2}$, Hyalle Abreu Viana ${ }^{4}$, \\ Alyne Fernandes Bezerra ${ }^{5}$, \\ Wanessa Toscano Cavalcante ${ }^{1}$, Sérgio Ribeiro dos Santos ${ }^{6}$, \\ Maurício Caxias de Souza ${ }^{7}$, \\ Rozileide Martins Simões Candeia ${ }^{8}$, Ericka Silva Holmes ${ }^{9}$, \\ Jaqueline Brito Vidal Batista ${ }^{3}$, \\ lolanda Beserra da Costa Santos ${ }^{10}$, \\ Aurilene Josefa Cartaxo Gomes de Arruda ${ }^{10}$, \\ Humberto Hugo Nunes de Andrade?, \\ Jaqueline Silva de Almeida ${ }^{11}$, \\ Geandro da Cunha Silva ${ }^{12}$, Wellyson Souza do Nascimento ${ }^{7}$, \\ Kirlene Scheyla Viana Chianca ${ }^{13}$, \\ Helida Maria Fernandes Brasil ${ }^{14}$
}

\section{Abstract}

Introduction: palliative care are a type of care directed to people with diseases without therapeutic possibility of cure, guided by a philosophy that emphasizes comprehensive care to the person, as opposed to actions that only seek a cure. According to the WHO, palliative care seeks quality of life of both patients and their families, from measures aimed at the prevention and relief of suffering.

Objective: to verify nursing professionals' concept on palliative care and determine how nursing professionals use palliative care in patients without therapeutic possibilities of cure.

Method: field study, exploratory, qualitative, conducted with 30 nursing professionals from a public hospital, using a questionnaire, during July and August 2013. This study was approved by the CEP of the HULW/UFPB, CAAE number: 16841113.6.0000.5183.

Results: four core ideas were extracted: Care focused on improving the quality of life of patients and families in coping terminal diseases; Essential care regardless of diagnosis; Palliative care is aimed at pa-
1 Nurse, Resident, Multiprofessional Integrated Residency in Hospital Health, University Hospital Lauro Wanderley. .

2 Nurse, MSc Professor at the Department of Clinical Nursing/DENC, PhD Student, Postgraduate Program in Nursing/PPGEnf, Federal University of Paraíba.*.

3 Nurse, PhD Professor, Graduate/ Postgraduate Program in Nursing/ PPGEnf, Federal University of Paraíba. .

4 Psychologist, PhD Student of the Postgraduate Program in Social Psychology, Federal University of Paraiba.*.

5 Nurse, Expert in Residence mode on Health of the Elderly, Master's degree, Postgraduate Program in Nursing/ PPGENF, Federal University of Paraíba.*.

6 Nurse, PhD Professor, Graduate/ Postgraduate Program in Nursing and Decision Models in Health (PPGMDS/ GEnf), Federal University of Paraíba.*

7 Graduating in Nursing.*.

8 Nurse. Specialist in Family Health.*.

9 Nurse. doctoral student in decision models and health by the Federal University of Paraíba.*.

$10 \mathrm{PhD}$ professor of clinical nursing department at the Federal University of Paraíba.*.

11 Clinical nurse.*

12 Care nurse Adult Infectious of the Hospital Clementino Fraga Complex ICU.*.

13 Nurse. Master in Nursing from the Federal University of Paraíba. *

14 Nurse. Hospital of Emergency and Trauma Senator Humberto Lucena. * *: João Pessoa (PB), Brazil.

\section{Contact information:}

\section{Ericka Silva Holmes.}

”ericka_holmes@hotmail.com 
tients without therapeutic possibilities of cure and at terminal phase; Routine care promotion with gestures of love and physical and spiritual support.

Conclusion: The concept of nursing professionals on palliative care is fragile and insufficient.

\section{Keywords}

Palliative Care; Nursing;

Terminal Care; Chronic

Disease.

\section{Introduction}

In recent decades, there has been a significant growth of people with chronic diseases that compromise the patient's condition, promoting significant suffering. Given this reality, the care of most health professionals focuses on the control of signs and symptoms that cause discomfort and suffering, making it one of the most frequent concerns of such professionals. [1]

The World Health Organization (WHO) defines as chronic diseases cerebrovascular, cancer, renovascular, cardiovascular, respiratory diseases and diabetes mellitus, considering that all of them require continuous and special care attention, combined with a set of equipment, public policy and people in general. [2]

In this perspective, knowing the extent of the suffering of patients with chronic diseases or those in its most advanced stage, without therapeutic possibility of cure or at terminal phase, it is urgent to develop an assistance based on palliative care. [3]

In this context, the definition of palliative care is a form of care directed to people with diseases without therapeutic possibility of cure, guided by a philosophy that emphasizes comprehensive care to the person, as opposed to actions that only seek the cure. [4]

According to the $\mathrm{WHO}$, palliative care seeks quality of life of both patients and their families, who have to face diseases that threaten the continuity of life, from measures aimed at the prevention and relief of suffering through early recognition, appropriate assessment and treatment of pain, but also includes symptoms of physical, psychosocial and spiritual nature. [5]

Therefore, it is necessary to have a holistic view of the person, focusing on pain relief and management of emotional and spiritual symptoms, and social well-being of the patient and his family, including spiritual care to meet the needs of most patients. [6]

Palliative care, in turn, are offered by a multidisciplinary team, adequately trained to recognize and work symptoms that go beyond the biological ones, that has a great potential for communication and understands the patient as an active subject, with the right to information and autonomy regarding the decisions of the treatment. [7] Therefore, for the promotion of palliative care, it is necessary a team composed of physicians, nurses, physiotherapists, psychologists, nutritionists, spiritual assistant, among other professionals.

For achieving the comfort, quality of life and human dignity at the time of finitude, $a$ it is necessary the commitment of diverse knowledge of an interdisciplinary team, ensuring, thus, success in the provision of palliative care. [8] However, added to the strong commitment of health professionals, palliative care is a specialty that requires the involvement of caregivers and family members as active subjects of the care process, not only by the weakness of the patient's condition, but also by the existential and spiritual angst involved. [6] 
In the context of palliative care, health professionals, especially nursing staff for staying in constant contact with hospitalized patients, knowing the entire context and interfering with the suffering, should seek, through their knowledge, to minimize any discomfort exposed by the patient or his/ her family, providing physical care, acting on the symptoms and providing emotional support, safeguarding the dignity until finitude. [9]

Therefore, it is undeniable the participation of nursing staff in the practice of palliative care. Hence, the importance of studies that seek to investigate the conception of nurses about that type of care, being an important tool to support educational activities, as it will provide fundamental information that will allow education in palliative care according to the needs presented by this population.

Given the exposed, this study had the following guiding question: what is the concept of nursing professionals about palliative care? How do nursing professionals use palliative care in patients without therapeutic possibilities of cure?

Therefore, this study aimed to verify nursing professionals' concept of palliative care and to assess how nursing professionals use palliative care in patients without therapeutic possibilities of cure.

\section{Method}

This research is an exploratory field study, with qualitative approach, carried out at a public hospital in the city João Pessoa, Paraíba, Brazil.

The study population involved nurses and midlevel nursing professional members of the hospital staff, represented by 167 nursing professionals, allotted at inpatient units selected for the research, which are: Medical Clinic, Infectious and Parasitic Diseases Clinic and Adult Intensive Care Unit.

The sample was obtained in a non-probabilistic way and by accessibility, in which each member has the same chance of being chosen. Therefore, the inclusion criteria were: being developing the work for more than a year in the sectors selected for the research; and accepting voluntarily to participate in the study by signing the Informed Consent Form. Based on these criteria, 30 nursing professionals participated in the study.

Data were collected through a questionnaire containing questions relevant to the proposed objectives, which are: What is your conception of palliative care? In your professional practice, how do you use the palliative care in patients without therapeutic possibilities of cure?

For starting the research, the researcher introduced herself to the professional participants and, then, the study objectives were displayed. Two copies of the Informed Consent form accompanied the request for participation in the study. In this document, there was information on the purpose of the research and the type of involvement of the participants. The disconnection between the research and surveyed health institution was assured, as well as the free consent, the freedom to withdraw from the study at any time, confidentiality and anonymity of the information, as required by Resolution No. 466/12, of the National Health Council. [10]

After the participants accepted the participation and signed Informed Consent Form, they answered the questionnaire without interference from the researcher. This was delivered to the participants in their workplaces and in moments of rest, as they involve professionals who are continuously connected to patient care, ensuring that there were no losses of care activities of the people under their responsibility.

Nevertheless, it is noteworthy that the survey was carried out only after referral, assessment and approval of the study by the Research Ethics Committee of the University Hospital Lauro Wanderley, under Opinion No. 336,199/2013, and CAAE: 16841113.6.0000.5183, and authorization to enter the data collection field by the Nursing Division. 
After collecting the data, the empirical material was analyzed through the Collective Subject Discourse (CSD) technique proposed by Lefèvre and Lefèvre. This analysis brings the opinion of the exposed community in frames of discourses that represent the different ways of social perception and representation of certain subject. [11]

Therefore, three methodological figures were used in the creation of the speeches tables: the key phrases that are the most significant passages of the answers; the central ideas that are the synthesis of discursive content expressed in key phrases; CSD speeches that are summaries of individual statements from fragments gathered by similarity of meanings and formulated in singular first person, prepared by the researcher and discourse analyst. [11] The data were presented in tables and discussed in light of the relevant literature.

\section{Results}

Regarding the characteristics of the sample, the results show a predominance of women, that is, 25 female professionals and five male professionals, demonstrated by the percentage values $83 \%$ and $17 \%$, respectively. This shows the female prevalence in the nursing profession [9], despite the male increasing adherence that has occurred over the last years.

Regarding the position that each one of the 30 participants exercises in nursing, 18 nurses and 12 mid-level nursing professionals participated in the study. The operating time in the hospital ranged from one year to 33 years, mean of 12.2 years, indicating that, in the hospital care, there are young professionals who started developing their activities recently, but most of them have been assisting the patients for few years.

Regarding the understanding of those professionals of palliative care, two central ideas arose: Care focused on improving the quality of life of patients and families in coping terminal diseases and Essential care regardless of diagnosis, as Table 1 shows.

Table 1. Central ideas and CSD in response to the question: what is your conception on palliative care? Source: Research empirical material.

\begin{tabular}{|c|c|}
\hline Central Idea 1 & CSD \\
\hline $\begin{array}{l}\text { Care focused on } \\
\text { improving the } \\
\text { quality of life } \\
\text { of patients and } \\
\text { families in coping } \\
\text { terminal diseases. }\end{array}$ & $\begin{array}{l}\text { Care provided to chronic patient or in } \\
\text { terminal phase [...], [...] that does not } \\
\text { aim to cure; [...] helping the patient at } \\
\text { the end of his/her life, as comfort; [...] } \\
\text { it aims to promote quality of life for } \\
\text { the patient and his/her family in order } \\
\text { to relieve the suffering; [...] it serves to } \\
\text { relieve pain and promote well-being } \\
\text { for them; [...] minimizing or controlling } \\
\text { undesirable signs and symptoms } \\
\text { presented by the patient; [...] often } \\
\text { non-medicated care, that can also use } \\
\text { medications, or other invasive forms; } \\
\text { [...] practiced in order to prevent future } \\
\text { occurrences and discomfort; [...] such } \\
\text { care are also physical, psychological and } \\
\text { social both for patients and for their } \\
\text { families; [...] maintaining dignity until the } \\
\text { end of life. }\end{array}$ \\
\hline Central Idea 2 & CSD \\
\hline $\begin{array}{l}\text { Essential care } \\
\text { regardless of } \\
\text { diagnosis. }\end{array}$ & $\begin{array}{l}\text { Nursing care essential to life and welfare } \\
\text { of the individual with any disease; [...] } \\
\text { Any procedure in favor of the patients } \\
\text { in their basic needs, just to make them } \\
\text { comfortable; [...] improve the patient's } \\
\text { hospital staying; [...] from the family and } \\
\text { multidisciplinary team consent. }\end{array}$ \\
\hline
\end{tabular}

Regarding professional practice, the participants were asked how they use the palliative care for patients without therapeutic possibilities of cure. Given the speeches, two central ideas and CSD emerged, arranged below, in Table 2, namely: Palliative care is aimed at patients without therapeutic possibilities of cure and at terminal phase; Routine care promotion with gestures of love and physical and spiritual support. 
Table 2. Central ideas and CSD in response to the question: in your professional practice, how do you use palliative care in patients without therapeutic possibilities of cure? Source: Research empirical material.

\begin{tabular}{|c|c|}
\hline Central Idea 1 & CSD \\
\hline $\begin{array}{l}\text { Palliative care } \\
\text { is aimed at } \\
\text { patients without } \\
\text { therapeutic } \\
\text { possibilities of cure } \\
\text { and at terminal } \\
\text { phase }\end{array}$ & $\begin{array}{l}\text { There are many admissions in order } \\
\text { to provide palliative care; I make it to } \\
\text { the patients admitted to the ICU with } \\
\text { suspected terminal illness [...], [...] to } \\
\text { terminal patients always when they } \\
\text { arrive at the medical clinic; [...] When } \\
\text { they are terminally ill, with cancer and } \\
\text { always to the patient who is close to } \\
\text { death, [...] in any situation that the } \\
\text { patient has a disease without curing } \\
\text { condition, then I provide palliative } \\
\text { care because he will feel better, [...] } \\
\text { I daily assist these patients and their } \\
\text { families, because, through such care, } \\
\text { they relieve suffering, [...]they should } \\
\text { be applied regardless of anything; [...] } \\
\text { thus, they keep the dignity of these } \\
\text { patients until death. }\end{array}$ \\
\hline Central Idea 2 & CSD \\
\hline $\begin{array}{l}\text { Routine care } \\
\text { promotion with } \\
\text { gestures of love } \\
\text { and physical and } \\
\text { spiritual support }\end{array}$ & $\begin{array}{l}\text { It is always held position change } \\
\text { and is given attention to the patient; } \\
\text { [...] The care that technicians can } \\
\text { perform, such bed bath; [...] I have an } \\
\text { opportunity every time I administer a } \\
\text { prescribed medication; by any routine } \\
\text { procedure such as dressing, feeding } \\
\text { and changing positions; [...] the care } \\
\text { is provided, [...] with a gesture of love } \\
\text { and physical and spiritual support } \\
\text { is the least, you can already feel } \\
\text { the accomplishment; nevertheless, } \\
\text { I always increasingly intensify [...]; } \\
\text { [...] I increasingly intensify, because } \\
\text { patients [...] need such care. }\end{array}$ \\
\hline
\end{tabular}

\section{Discussion}

Palliative care is any care provided to patients with diseases that threaten the continuity of life, and who are under the control of pain and other symptoms of psychological, social and spiritual order, in order to obtain higher quality of life for both the patients and their family. [1] This care method, in the health context, is a proposal of care for people with more advanced disease, offering them comfort and health promotion. [3]

Thus, palliative care provides patients without therapeutic possibility a dignified death, seeking a better quality of life through care that persist in the family mourning period. [12, 2]

Considering the mentioned literature, regarding the nursing professionals' concept about palliative care, their speeches reveal that some professionals understand what is palliative care and its purposes, demonstrating responses that are consistent to what was asked. However, they have superficial and limited knowledge on the subject. Another part of the participants responded in a way that shows their lack of knowledge.

Despite the consistency in most of the professionals' responses, a discourse stated it was a care provided to a patient without prognosis, restricting it to nursing professionals as technical practitioners of palliative care to meet the patients' basic needs, which shows lack of knowledge. The references address palliative care as a technique that has as one of its main features the multidisciplinary care and meeting the needs are basic nursing care.

Another statement states that the palliative technique needs the family and the health team consent. Nevertheless, the palliative medicine affirms the patient's autonomy in the treatment and the professional develops palliative care without the need for the consent of other professional from the staff, being the author of the care and, more than that, working in a team in which everyone has autonomy in the multidisciplinary and interdisciplinary perspective.

However, only two participants mentioned the family as part of the care, which reflects the deficiency of nursing professionals to involve the patient's family in the care. They should do so in order to 
provide the patients the best quality of life and to help them in such a crucial moment, when they face the disease course and the stages of grief.

In another aspect, they say that palliative care is offered to any patient regardless of his/her diagnosis, just to ease the hospitalization period, demonstrating they lack knowledge on the theme.

As for the use of palliative care to patients without therapeutic possibilities of cure during the professional practice of the participants, only two responded not practicing palliative care.

Although most participants have stated they practice such care, they showed difficulties in reporting how they use such care facing patients without therapeutic possibilities of cure, making it clear the confusion regarding the understanding of the theme.

Some speeches, once again, did not square the palliative care, revealing that, despite the positive affirmation of the majority of the participants, it does not necessarily mean they practice such care.

Although CSD of the Central Idea 1 clearly reports the provision of palliative care within the principles for their care, some speeches are beyond the line, stating they adopt the strategy only to cancer patients. However, although such assistance is one of the palliative care philosophy goals because the cancer belongs to the group of diseases that require attention from caregivers, this technique is not limited to this, going far beyond of what was said.

It is noteworthy that, in Brazil, the practice of palliative care was initially associated with the patient with terminal cancer; however, this concept expanded to patients with chronic diseases such as cerebrovascular, cardiovascular, renovascular, respiratory and diabetes mellitus, after the definition of chronic diseases and palliative care by the World Health Organization. [3]

In CSD of the Central Idea 2, some professionals come into contradiction when reporting they use palliative care, involving on the one hand, routine nursing care and, in another aspect, emotional issues and physical and spiritual support allied to such routines as palliative methods for patients without therapeutic possibilities of cure.

In the sense of palliative care, nursing professionals should develop a more effective assistance of the problems of families and patients in such situations, their support should go beyond the techniques they use in their routines. [14]

Using communication strategies and emotional support to patients and their families, for example, is a condition for the multidimensional care to occur and be effective. [15] Providing support and engaging emotionally with the patient during care does not necessarily mean that is the provision of palliative care.

Actively listening in palliative care means attention to the other, valuing their needs in all contexts. [15] Communication is also essential to meet the needs of the family, both in the relationship with the nursing staff, with their loved one, as even among the own interdisciplinary team. [16]

Despite the incoherence of speeches and lack of knowledge of the subject by some participants, it is remarkable that professionals, somehow, try to involve palliative care during service, which turns out to be a breakthrough in nursing.

The dispersion of this care is growing gradually to meet the demands of patients in need of professionals who work with different care modalities. Thus, the intention is that, in the medium term, there is an expansion in the country, with more professionals working in this area, as they are already fighting for changes in legislation that benefit the expansion of this care. $[15,17]$

\section{Conclusion}

The study identified deficiency in the nursing professionals' conception about palliative care, which can be considered as a negative factor to provide this type of care to patients and their families. We 
noticed the superficiality and inadequacy of this knowledge when evaluating the gathered information.

Awareness of nursing professionals to carry out the palliative care in their professional practice is extremely important, since they are facing people who need not only clinical interventions, but also care that mitigate their suffering in various dimensions, demonstrating the need to develop a care that is scientific and humanistic.

The issue becomes extremely important in the current socio-political context, for there has been a significant increase in people needing special care. The expectation is that, from the results of this study, the health team, especially nursing, can trigger a process of reflection about the provision of palliative care given their work process, building a comprehensive and humanized care to chronic patients without therapeutic possibility of cure or terminally ill and their families, enhancing care with autonomy and responsibility.

Therefore, an educational investment becomes necessary, based on a better professional qualification, as well as the creation of a public policy for palliative care.

Some institutions are already entering the theme of care at the end of life in their disciplines, despite the still existing superficiality. However, it is still necessary a stronger educational investment, since professionals who have only the technical basic training or graduation are not prepared to face this dimension of care.

In addition, it is important to conduct professional training and ongoing education of those who already carry out their functions, renewing their practices for the effective implementation of palliative care. Thus, the knowledge about the technique can guarantee autonomy to professionals, encouraging them to change their behavior when facing people who experience the end of life.

However, it is noteworthy that obtaining new knowledge brings no guarantee for the change of behaviors that can positively influence the assistance. Therefore, there should be a stronger and more focused policy, since the provision of palliative care to chronic patients or without therapeutic possibilities is a matter of public health.

\section{References}

1. Waterkemper R, Reibnitz KS. Cuidados paliativos: a avaliação da dor na percepção de enfermeiras. Rev Gaucha Enferm. 2010 [access on Aug 10, 2013]; v. 1, n. 31, p. 91-84. Available from: http://www.scielo.br/pdf/rgenf/v31n1/a12v31n1.pdf.

2. Ministério da Saúde (Brasil). Instituto Nacional do Câncer. Estimativa 2012: incidência de câncer no Brasil. Rio de Janeiro. 2011.

3. Sales CA, Silva VA. A atuação do enfermeiro na humanização do cuidado no Contexto hospital. Cienc cuid saúde. 2011; v. 1 n. 10, p. 066-73.

4. Silva MM, Moreira MC, Leite JL, Erdmann AL. Analysis of nursing care and the participation of families in palliative care in cancer. Texto Contexto Enferm. 2012 [cited 2013 aug 11]; v. 3, n. 21, p. 658-66. Available from: http://www.scielo.br/pdf/tce/v21n3/ en v21n3a22.pdf.

5. World Health Organization (2006). Definition of Palliative Care. WHO, Geneva [cited 2013 aug 9]. Available from: http://www. who.int/cancer/palliative/definition/en/

6. Freire Filho PAM, Almeida SB, Siebra DBA, Lavor IAM, Cavalcante $A A$, Saraiva ACL et al. Family Relations and Spiritual Response to Palliative Care: a Review of Literature. International Archives of Medicine. 2016; v. 9, n. 87

7. Silva Filho SRB, Lôbo RR, Lima NKCL, Ferriolli E, Moriguti JC. Cuidados Paliativos em enfermaria de Clínica Médica. Medicina (Ribeirão Preto). 2010 [access on Aug 12, 2013]; v. 2, n. 43, p. 126-33. Available from: http://revista.fmrp.usp.br/2010/vol43n2/ Simp4 Cuidados $\% 20$ paliativos $\% 20$ em $\% 20$ enfermaria $\% 20$ de\% 20cl\%EDnica\%20m\%E9dica.pdf.

8. Silva MM, Moreira MC, Leite JL, Erdmann AL. El trabajo nocturno de la enfermería en el cuidado paliativo oncológico. Rev Latino-Am Enfermagem. 2013 [access on Aug 18, 2013]; v. 3, n. 21. Disponible en: http://www.scielo.br/pdf/rlae/v21n3/ es 0104-1169-rlae-21-03-0773.pdf.

9. Silva KS, Kruse MHL. Em defesa da sociedade: a invenção dos cuidados paliativos e a produção de subjetividades. Rev Esc Enferm USP. 2012 [access on Aug 15, 2013]; v. 2, n. 46, p. 460-5. Available from: http://www.scielo.br/pdf/reeusp/v46n2/ a26v46n2.pdf.

10. Ministério da Saúde (BRASIL). Conselho Nacional de Saúde. Resolução 466, de 12 de dezembro de 2012: diretrizes e normas regulamentadoras de pesquisa envolvendo seres humanos. Brasília-DF. 2013. 
11. Lefevre F, Lefevre AMC. Discurso do Sujeito Coletivo: um novo enfoque em pesquisa qualitativa (Desdobramentos). Caxias do Sul, RS: Educs; 2005

12. Silva KS, Kruse MHL. As sementes dos cuidados paliativos: ordem do discurso de enfermeiras. Rev Gaucha Enferm. 2009; v. 2, n. 30, p. 183-90.

13. Monteiro FF, Oliveira M, Vall J. A importância dos cuidados paliativos na enfermagem. Rev Dor. 2010 [access on Aug 19, 2013]; v.3, n.11, p.242-8. Available from: http://www.dor.org. br/revistador/Dor/2010/volume 11/n\%C3\%BAmero 3/pdf/ volume 11 n 3 pags 242 a 248.pdf.

14. Silva MMS, Moreira MC. Sistematização da assistência de enfermagem em cuidados paliativos na oncologia: visão dos enfermeiros. Acta Paul Enferm. 2011 [access on Aug 19, 2013]; v. 2, n. 24, p.172-8. Available from: http://www.scielo.br/pdf/ ape/v24n2/03.pdf.

15. Araújo MMT, Silva MJP. O conhecimento de estratégias de comunicação no atendimento à dimensão emocional em cuidados paliativos. Texto Contexto Enferm. 2012 [access on Aug 24, 2013]; v. 1, n. 21, p. 121-9. Available from: http://www. scielo.br/pdf/tce/v21n1/a14v21n1.pdf.

16. Fonseca JVC, Rebelo T. Necessidades de cuidados de enfermagem do cuidador da pessoa sob cuidados paliativos. Rev Bras Enferm. 2011[access on Aug 24, 2013]; v. 1, n. 64, p. 180-4. Available from: http://www.scielo.br/pdf/reben/v64n1/ v64n1a26.pdf

17. Mendonça ACA, Moreira MC, Carvalho V. Atenção paliativa oncológica em Unidade Terapia Intensiva. Esc Anna Nery. 2012 [access on Aug 26, 2013]; v. 4, n. 16, p. 817-23. Available from: http://www.scielo.br/pdf/ean/v16n4/25.pdf.
Publish in International Archives of Medicine

International Archives of Medicine is an open access journal publishing articles encompassing all aspects of medical science and clinical practice. IAM is considered a megajournal with independent sections on all areas of medicine. IAM is a really international journal with authors and board members from all around the world. The journal is widely indexed and classified Q2 in category Medicine. 